\title{
Eltrombopag-induced recurrent stroke in idiopathic thrombocytopenic purpura
}

\author{
Yukinori Maeda, ${ }^{1}$ Daisuke Yamamoto, ${ }^{1}$ Yotaro Tamai ${ }^{2}$
}

'Department of Neurology, Shonan Kamakura General Hospital, Kamakura, Japan ${ }^{2}$ Department of Hematology, Shonan Kamakura General Hospital, Kamakura, Japan

\section{Correspondence to} Dr Daisuke Yamamoto; daisukeneurology@gmail.com

Accepted 19 March 2021

\section{DESCRIPTION}

A 75-year-old woman was diagnosed with primary idiopathic thrombocytopenic purpura (ITP). The patient had no history of thrombotic events. We could not administer the standard dose of glucocorticoid because of her old age, and her platelet count did not increase with glucocorticoid monotherapy. According to the international guidelines, ${ }^{1}$ intravenous immunoglobulin (IVIg) therapy is recommended in this situation. However, we could not choose IVIg therapy because of the insurance system in our country; therefore, eltrombopag $(12.5 \mathrm{mg} /$ day $)$ was administered. The patient did not undergo splenectomy. Left hemiplegia developed 1 month after the initiation of eltrombopag. The patient's platelet count was $116 \times 10^{9} / \mathrm{L}$ on admission. In addition, brain MRI showed multifocal cerebral infarctions in the right hemisphere (figure 1A,B). We suspected cardiogenic thrombosis from her imaging findings. Therefore, we started intravenous heparin, followed by apixaban; however, a follow-up MRI showed recurrent cerebral infarction (figure 1C,D). After a second ischaemic attack, intravenous heparin therapy was administered again, but another ischaemic attack occurred (figure 2). No antiphospholipid antibodies or concomitant

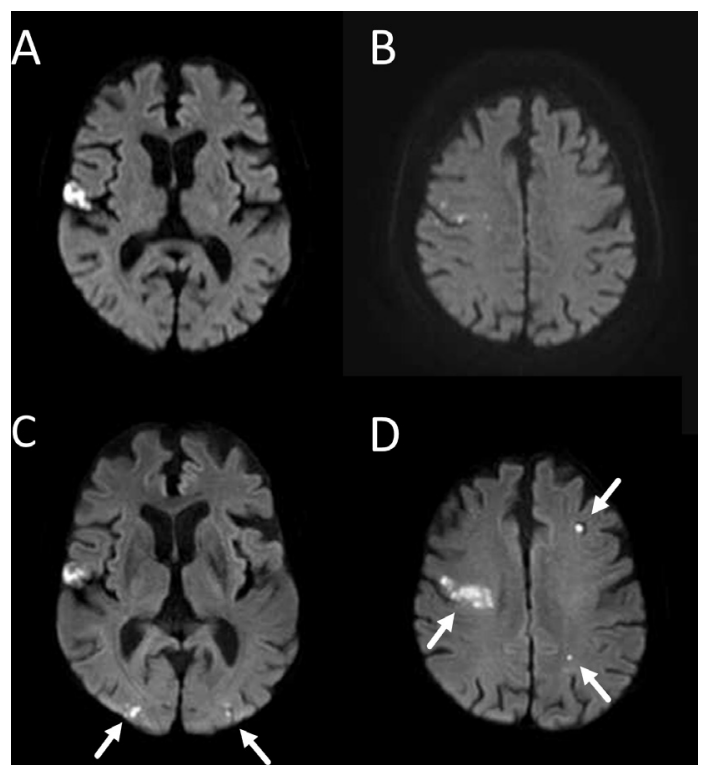

Figure 1 (A, B) Diffusion-weighted MRI (DW-MRI) on admission (day 35 ) shows multiple high-intensity spot lesions in the right frontal lobe. (C, D) DW-MRI on day 41 shows other infarct lesions on both hemispheres of the brain (arrow).

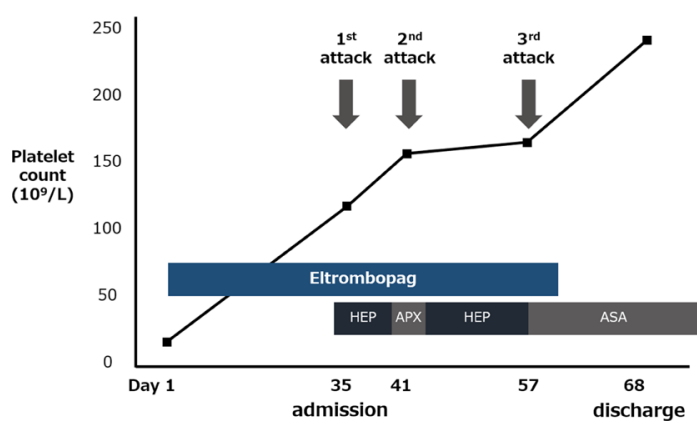

Figure 2 Clinical course of the patient. The patient developed cerebral infarction three times during the use of eltrombopag. After eltrombopag was discontinued, the patient did not experience any recurrent stroke. APX, apixaban; ASA, acetylsalicylic acid; HEP, heparin.

inherited risks for thrombosis were detected. Eltrombopag was suspected to be responsible for the stroke. No subsequent recurrence of stroke existed after eltrombopag was stopped. Eventually, acetylsalicylic acid was administered to prevent stroke.

Studies have shown that ITP could cause stroke. The increased level of platelet microparticles in patients with ITP could be associated with the development of thrombosis. ${ }^{2}$ However, some studies have suggested that eltrombopag causes thrombosis, including cerebral infarction. ${ }^{3}$ The risk of eltrombopag-induced adverse effects should be considered in patients with ITP, who develop cerebral infarction.

Learning points

- In patients with idiopathic thrombocytopenic purpura (ITP), the risk of stroke should be considered.

- In addition, stroke could be caused after ITP treatment.

- Eltrombopag could be a cause of thrombosis, including cerebral infarction, even when the platelet count is normal.

Contributors YM was a major contributor in writing the manuscript. DY and YT also treated the patient, and interpreted the patient data. All authors read and approved the final manuscript.

Funding The authors have not declared a specific grant for this research from any funding agency in the public, commercial or not-for-profit sectors,

Competing interests None declared.

Patient consent for publication Obtained. 


\section{Images in...}

Provenance and peer review Not commissioned; externally peer reviewed.

\section{REFERENCES}

1 Neunert C, Terrell DR, Arnold DM, et al. American Society of hematology 2019 guidelines for immune thrombocytopenia. Blood Adv 2019;3:3829-66.
2 Yunoki M, Suzuki K, Uneda A, et al. Multiple cerebral infarctions in a patient with idiopathic thrombocytopenic purpura. Iran J Neurol 2016;15:177-9.

3 Wong RSM, Saleh MN, Khelif A, et al. Safety and efficacy of long-term treatment of chronic/persistent ITP with eltrombopag: final results of the extend study. Blood 2017; 130:2527-36.

Copyright 2021 BMJ Publishing Group. All rights reserved. For permission to reuse any of this content visit https://www.bmj.com/company/products-services/rights-and-licensing/permissions/

BMJ Case Report Fellows may re-use this article for personal use and teaching without any further permission.

Become a Fellow of BMJ Case Reports today and you can:

- Submit as many cases as you like

Enjoy fast sympathetic peer review and rapid publication of accepted articles

Access all the published articles

Re-use any of the published material for personal use and teaching without further permission

\section{Customer Service}

If you have any further queries about your subscription, please contact our customer services team on +44 (0) 2071111105 or via email at support@bmj.com.

Visit casereports.bmj.com for more articles like this and to become a Fellow 